\title{
Plains larkspur (Delphinium geyeri) grazing by cattle in Wyoming
}

\author{
JAMES A. PFISTER, DALE R. GARDNER, BRYAN L. STEGELMEIER, ANTHONY P. KNIGHT, JAMES W. \\ WAGGONER, JR., AND JEFFERY O. HALL
}

Pfister, Gardner and Stegelmeier are Rangeland Scientist, Research Chemist, and Veterinary Pathologist, respectively, USDA-ARS Poisonous Plant Research Lab., 1150 E. 1400 N., Logan, Ut. 84341; Knight is Dept. Head, Veterinary Clinical Science, Colorado State Univ., Ft. Collins, Colo; Waggoner is Associate Professor, Dept. of Renewable Resources, University of Wyoming, Laramie, Wyo.; Hall is Veterinary Toxicologist, Dept. of Animal, Dairy, and Vet. Sci., Utah State University, Logan, Ut. 84322. Pfister's email is jpfister@cc.usu.edu.

\section{Abstract}

Plains larkspur (Delphinium geyeri Greene) is a major cause of cattle deaths in the northern Great Plains of Wyoming and Colorado. We examined the amount and timing of larkspur ingestion by grazing cattle in relation to larkspur phenology, nutrient concentrations, and weather conditions. Four summer grazing trials were conducted near Cheyenne (1996 and 1997) and Laramie, Wyo. (1998 and 1999). All trials began when plains larkspur was vegetative or in the early bud stage. In the first 2 studies, 6 yearling heifers grazed from 3 May to 4 August 1996; the same animals plus $5 \mathrm{cow}$-calf pairs grazed from 13 May to 10 August 1997. During both 1996 and 1997, cattle ate 0.5 to $1 \%$ of bites as larkspur during May, then consumption decreased to nearly 0 during the remainder of both summers. When eaten, larkspur was typically consumed during cool, foggy weather conditions. In the last 2 studies, 6 cow-calf pairs grazed near Laramie, Wyo., from 13 May to 30 June 1998, and 6 different cow-calf pairs grazed from 2 June to 20 July 1999. Cattle ate substantial amounts of plains larkspur (herd average $\sim 3 \%$ ) during the vegetative and bud stages from mid-May into early June, 1998. Cattle may have eaten more larkspur during 1998 because drought reduced spring availability of green grass. Consumption of larkspur was negatively related $\left(r^{2}=0.43\right)$ to daily temperature in 1998, but not during 1999. During 1999 cattle ate essentially no plains larkspur during the vegetative and bud stages, but ate larkspur (herd average $\sim 5 \%$ ) during the flower and pod stages when larkspur plants were beginning to desiccate and ambient temperatures were above average. This series of trials indicates that it will be difficult to predict plains larkspur consumption based on larkspur growth patterns or weather. Although cattle sometimes increase plains larkspur consumption when temperatures are cooler than normal, this pattern is not consistent enough to serve as a basis for management recommendations.

Key Words: toxic plants, diet selection, cattle grazing, methyllycaconitine, alkaloids

The authors wish to thank Kermit Price, Dirk Salmon, Dr. Mike Smith, Dr Mike Ralphs, Lee Woolsey, Jeff Salmon, Al Maciulis, Rex Probst, Danny Hansen, Jason Dormady, and Rick Shea for assistance with various aspects of the study. We appreciate the generous cooperation provided by Jerry Johnson and Mike McGraw, Belvoir Ranch, Cheyenne, Wyoming, and Andy and Mark Johnson, Johnson Ranch, Laramie, Wyoming.

Manuscript accepted 24 Oct. 2001

\section{Resumen}

El "Plains larkspur" (Delphinium geyeri Greene) es la principal causa de muerte de ganado en las Grandes Planicies del norte de Wyoming y Colorado. Examinamos la cantidad y tiempo de ingestión de "Larkspur" por el ganado en apacentamiento en relación a la fenología del "Larkspur", la concentración de nutrientes y las condiciones climáticas. Se condujeron cuatro ensayos de apacentamiento de verano cerca de Cheyenne (1996 y 1997) y Laramie (1998 y 1999). Todos los ensayos iniciaron cuando el "Plains larkspur"estaba en etapa vegetativa o inicios de brotación de yemas. En los primeros dos estudios, 6 vaquillas de un año apacentaron del 3 de mayo al 4 de agosto de 1996; los mismos animales mas 5 pares de vaca-becerro apacentaron del 13 de mayo al 10 de agosto de 1997. En Mayo de ambos años, 1996 y 1997, del 0.5 a $1 \%$ de las mordidas del ganado fueron de “Larkspur", después, en el resto del verano, el consumo decreció a casi cero. Cuando el "Larkspur" fue consumido típicamente ocurrió cuando el clima era frío y neblinoso. En los últimos dos estudios 6 pares de vaca-becerro apacentaron cerca de Laramie, Wyoming del 13 de mayo al 30 de junio de 1998 y 6 pares de vaca-becerro diferentes apacentaron del 2 de junio al 20 de julio de 1999. Durante las etapas vegetativa e inicio de brotación de yemas, de mediados de mayo a inicios de junio de 1998, el ganado comió cantidades substanciales de "Plains larkspur" (promedio del hato $\sim 3 \%$ ). El ganado pudo haber comido mas 'Larkspur'durante 1998 porque la sequía redujo la disponibilidad de forraje verde en primavera. En 1998, el consumo de "Larkspur" fue relacionado negativamente $\left(r^{2}=0.43\right)$ con la temperatura diaria, pero esto no sucedió en 1999. Durante 1999 el ganado esencialmente no comió "Plains larkspur" durante las etapas vegetativas e inicio de brotación de yemas, pero comió "Larkspur" durante los estados de floración y fructificación (promedio del hato $\sim 5 \%$ ) cuando las plantas de "larkspur" comenzaron a desecarse y las temperaturas ambiente estuvieron arriba del promedio. Esta serie de estudios indica que basados en los patrones de crecimiento o clima será difícil predecir el consumo de "Plains larkspur". Aunque el ganado algunas veces incrementa el consumo de "Plains larkspur" cuando las temperaturas son mas frías de lo normal, este patrón no es lo suficientemente consistente para servir como base para recomendaciones de manejo. 
Plains larkspur (Delphinium geyeri Greene) is a major cause of cattle poisoning in the northern Great Plains of Wyoming and Colorado (Chesnut 1898, Beath 1919, 1925). The perennial larkspur typically begins growth in spring before grasses and other forbs have begun growth, and thus may offer green forage while grasses are dormant (Chesnut 1898). Plains larkspur contains numerous diterpenoid alkaloids, but the principal toxins are methyllycaconitine (MLA) and nudicauline (Manners et al. 1995).

No grazing studies have examined cattle consumption of plains larkspur. The objective of this study was to evaluate the amount and timing of larkspur consumption by cattle in relation to its phenology, toxicity, and other potentially important variables such as weather.

\section{Materials and Methods}

\section{Cheyenne 1996 and 1997}

Two trials were conducted during 1996 and 1997 on the Belvoir Ranch about 15 $\mathrm{km}$ west of Cheyenne, Wyo. (41 ${ }^{\circ} 5.40^{\prime} \mathrm{N}$ $105^{\circ} 0.31^{\prime} \mathrm{W} ; 2,026 \mathrm{~m}$ elevation). Western wheatgrass (Pascopyrum smithii [Rydb.] A. Love) and blue grama (Bouteloua gracilis [H.B.K.] Lag. ex Steud.) were the dominant constituents of the vegetation on the mixed grass prairie site; plains larkspur was a major forb.

Forage availability was determined at the beginning and end of the grazing trials by clipping $30,0.25 \mathrm{~m}^{2}$ quadrats placed along 2 pace transects through the pasture. Clipped samples were placed into paper bags, and oven-dried at $60^{\circ} \mathrm{C}$ to a constant weight. Density of plains larkspur was determined by counting the number of larkspur plants in $300,0.25 \mathrm{~m}^{2}$ quadrats placed systematically along 3 pace transects.

Larkspur phenology was assessed by marking 30 plants just outside the study pasture, and weekly observations were made on each plant. Larkspur plants were collected weekly for toxic alkaloid and nutrient analysis (see below). Twenty larkspur plants at each phenological stage were harvested and composited by growth stage. These weekly samples were frozen in plastic bags, freeze-dried, ground through a 1-mm screen, then analyzed for concentrations of toxic alkaloids by electrospray mass spectrometry (Gardner et al. 1999).

Grass samples for nutrient analysis were clipped weekly from five, $0.25 \mathrm{~m}^{2}$ plots in 5 representative areas of the pasture, oven dried at $40^{\circ} \mathrm{C}$ to a constant weight, then ground to pass a $1-\mathrm{mm}$ screen in a Cyclone grinder. Grass and larkspur samples were composited for each week, and then analyzed for neutral detergent fiber (NDF) using dacron bags in a modification of the Van Soest et al. (1991) method. Plant tissue was extracted with boiling neutral detergent using filter bags in a batch fiber analyzer (ANKOM, Fairport, N.Y.). An elemental analyzer (NA 2100 Protein Nitrogen Analyzer, ThermoQuest Italia S.p.A., Milan, Italy) was used to determine nitrogen content, and crude protein content was calculated (AOAC 1990).

Grass and larkspur samples were also analyzed for micronutrient concentrations using Inductively Coupled Plasma Mass Spectroscopy (ICP-MS). Plant tissue was digested via a modification of EPA method 3050 (Smith 1994). Digestions were performed in screw-cap teflon tubes, using $0.5 \mathrm{~g}$ of ground plant material in 10 $\mathrm{ml}$ of trace metal grade nitric acid at $90^{\circ} \mathrm{C}$ for 2 hours. The plant digests were diluted with $18.3 \mathrm{ml}$ of ultrapure water to $5 \%$ nitric acid prior to analysis. Standard curves for each element consisted of 5 concentrations between 10 and 2,500 ng $\mathrm{ml}^{-1}$. Quality control checks and standard curves were analyzed every 5 samples.

A moderate stocking rate was used during all trials. Six yearling heifers $(305 \mathrm{~kg})$ grazed from 3 May to 4 August 1996 on the 15 ha pasture. Heifers had not been previously exposed to larkspur. The trial began when plains larkspur was 3 to $6 \mathrm{~cm}$ tall (i.e., vegetative). The trial was divided into 4 periods corresponding to larkspur phenology: vegetative ( 3 to 16 May), vegetative/bud (17 May to 7 June), bud/early flower (8 June to 11 July), and flower/pod (12 July to 4 August). During 1997, 5 of the same heifers (then 2 years old) grazed the study site, plus an additional 5 cowcalf pairs that had no previous experience with plains larkspur. Cattle grazed from 13 May to 10 Aug 1997, and the study pasture was enlarged to 24 ha. The trial was divided into 4 periods corresponding to larkspur growth: vegetative (13 to 24 May), vegetative/bud (26 May to 25 June), flower (26 June to $10 \mathrm{July}$ ), and late flower/pod (11 July to 10 August). Trace mineral blocks were offered free choice during this and all subsequent trials.

Daily bite counts were used to determine animal diets (Pfister et al. 1997b). Beginning at 0700 hours every day, individual animals were focally sampled (Altmann 1974) in a predetermined random order. Each animal was observed in turn for 5 minutes. After all animals had been observed, the process was repeated during all active grazing periods until about 1900 hours, when cattle were placed in a corral for the night. Bites were categorized as grasses, other forbs, and larkspur bud, flower, pod, leaf, leaf and stem, or whole plant. We defined an individual bite as a single cropping motion, always indicated by a head jerk, often accompanied by a visible sweep of the tongue, and independent of chewing motions.

Weather variables (temperature, barometric pressure, relative humidity, wind speed and direction, precipitation) were monitored on site during the grazing studies using an automated weather station (Campbell Scientific, Logan, Ut.). Climatology information was supplemented using data from the Cheyenne airport located $18 \mathrm{~km}$ from the study site.

\section{Laramie 1998 and 1999}

Two trials were conducted on the Laramie Plains about $10 \mathrm{~km}$ southwest of Laramie, Wyo. (41 ${ }^{\circ} 17.19^{\prime} \mathrm{N} 105^{\circ} 43.83^{\prime}$ W; 2,225 m elevation). Larkspur density, phenology, and alkaloid concentration were determined as detailed above. Forage availability and nutrient status was determined by clipping weekly and handling the samples as noted above, except that grass samples for nutrient analysis were inadvertently discarded in 1998 . Forbs were generally a minor component in the vegetation each year, except for 1999. Because of a tremendous growth of Drummond's milkvetch (Astragalus drummondii Dougl. ex. Hook.) on the site during 1999, we sampled milkvetch and other forbs in addition to grasses and larkspur. We separated dry and green grass in 1998, but did not in 1999 as drought and grazing the previous year greatly reduced the amount of residual dry grass on the study site.

During 1998, 6 cow-calf pairs grazed on the 16 ha pasture from 13 May to 30 June. Based on larkspur phenology, the 48-day trial was divided into 4 periods corresponding to vegetative/early bud (14 to 25 May), bud stage (26 May to 6 June), late bud/early flower with most plants green ( 7 to 18 June), and late bud/flower with most plants becoming desiccated (19 to 30 June). During 1999 the pasture was enlarged to 20 ha, and was grazed by 6 different cow-calf pairs from 2 June to 20 July. Based on larkspur phenology in 1999, the trial was divided into 3 periods: vegetative/early bud (2 June to 11 June); bud/early flower (12 June to 2 July); flower/early pod (3 July to 20 July). As far as we know, larkspur was a novel food for all animals at the beginning of each summer's trial near Laramie. During 1998 and 1999 , bite counts began at dawn (0500 to 
0520 hours) each day and continued during active grazing periods until about 1800 hours. The cattle were placed into a corral each evening and group-fed $600 \mathrm{~g} \mathrm{head}^{-1}$ of a mix of rolled barley and melengesterol acetate $\left(550 \mathrm{mg} \mathrm{cow}^{-1}\right.$ day $\left.^{-1}\right)$ to prevent estrus and avoid interference from bulls grazing the adjoining pasture.

Weather variables were measured using an automated weather station as noted previously. Climatology information was supplemented using data from the Laramie airport located $7 \mathrm{~km}$ east of the study site.

\section{Statistical Analysis}

Bite count data were analyzed using the GLM procedure of SAS (1998). Each year was analyzed separately, with animals considered as blocks, and periods as treatments, with repeated measurements over days within periods. Stepwise multiple regression was used to examine relationships between larkspur consumption (the dependent variable) and weather and forage nutrient variables. Larkspur consumption in relation to weather was examined in 12 and 24 hour blocks. Mineral values for plants were averaged by weeks to provide a monthly mean. Regression analysis to relate forage nutrient (i.e., mineral, NDF, and crude protein) concentrations were done using weekly averages for larkspur consumption. No statistical analysis was done on weekly protein, NDF, or alkaloid concentrations from the composited samples.

\section{Results}

\section{Cheyenne 1996 and 1997 \\ Weather}

Average daily temperatures were close to normal during 1996 and from May to August 1997, but were colder than normal during April 1997 (Fig. 1). Summer precipitation was near or exceeded normal amounts during both years (Fig. 1). Summer forage production is highly correlated with precipitation during March, April and early May (Rauzi 1964, Hart and Samuel 1985), and during both years precipitation during those months was close to normal.

\section{Forage Availability}

About $80 \%$ of the available forage was grass during the 2 trials near Cheyenne, with plains larkspur comprising about 6 to $12 \%$ of the standing crop (Table 1). In general, forbs other than larkspur were a minor component of the standing crop in the pasture.
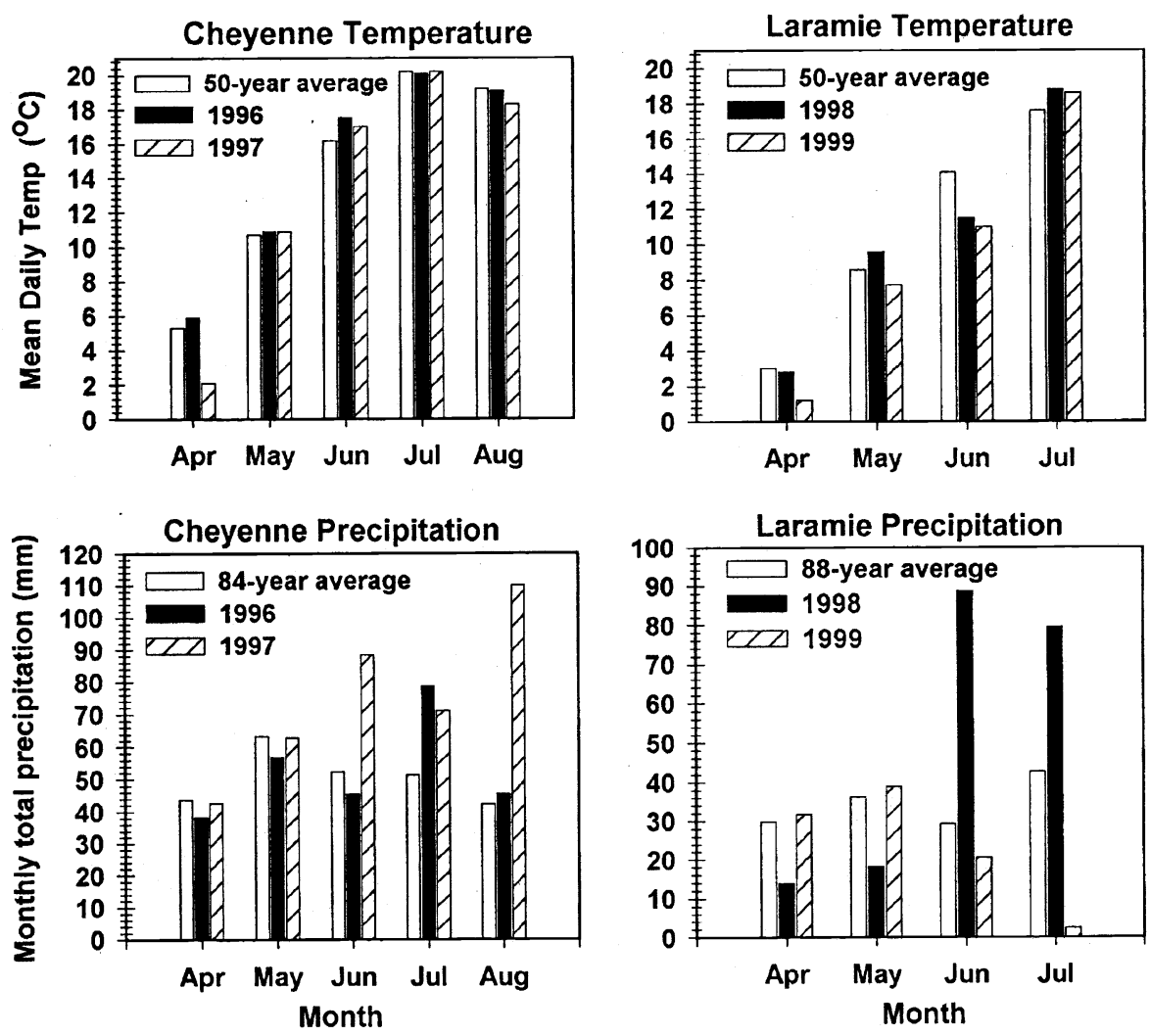

Fig. 1. Temperature (monthly average in degrees $\mathrm{C}$ ) and precipitation (monthly total in $\mathrm{mm}$ ) during spring and summer grazing trials for Cheyenne (1996 and 1997) and Laramie, Wyo. (1998 and 1999).

\section{Larkspur Density, Phenology and Alkaloid Concentration}

Larkspur density was 2.4 and 2.2 plants $\mathrm{m}^{-2}$ during 1996 and 1997, respectively. All larkspur plants were vegetative when the grazing study began in early May each year (Fig. 2). During 1996 larkspur growth was diverse, with some plants maturing while others were emerging. Most larkspur plants were fully mature or dead by late July, 1996. Growth was initially slower and more uniform during 1997, but in late June larkspur plants quickly began flowering. These flowering plants were slow to produce pods, and many larkspur plants senesced during mid-to-late July, 1997.

Plains larkspur plants during 1996 were highly toxic ( $>6 \mathrm{mg}$ toxic alkaloid $\mathrm{g}^{-1}$ plant dry matter) early in the vegetative stage (Table 2), and remained moderately toxic (3-6 $\mathrm{mg} \mathrm{g}^{-1}$ ) until mid July when they were in the late flower or pod stages of growth. Larkspur plants showed similar patterns during 1997, except that vegetative plants were not as high in alkaloid concentrations as in 1996, and concentrations remained moderately toxic ( $>3 \mathrm{mg}$ $\mathrm{g}^{-1}$ ) even when plants were largely senescent in early August (Fig. 2).

\section{Cattle Diets}

Cattle ate about $1 \%$ of bites as larkspur during May 1996, then consumption decreased to nearly 0 in June. Cattle ate essentially no larkspur during the last 2 months of the study during 1996 (data not shown), and periods did not differ ( $\mathrm{P}>$ 0.10). Over the entire 1996 trial, grasses and other forbs comprised 91.7 and $8.0 \%$ of bites, respectively. The only day of substantial larkspur consumption was 17 May 1996, a hot (maximum temperature $30^{\circ} \mathrm{C}$ ) and windy day. Two cows ate up to $30 \%$ of their bites as larkspur leaves and stems during several grazing bouts, and one was visibly intoxicated during the afternoon. Visible signs included staggering gait, muscular tremors, and periodic sternal recumbency.

Larkspur consumption was very low $(<$ $0.2 \%$ of bites) during all periods in 1997 , and periods did not differ $(\mathrm{P}>0.10)$ On 2 cold, damp days (19 and 21 May 1997) 2 cows ate $>15 \%$ of bites as larkspur in the morning, but showed no signs of intoxication. Nonetheless, there was no relationship $P>0.1$ ) between weather variables and larkspur consumption. Cattle diets were primarily grasses $(93.5 \%)$ and other forbs $(>6 \%)$ during the 1997 trial. 
Table 1. Standing crop $\left(\mathrm{kg} \mathrm{ha}^{-1}+\mathrm{SE}\right)$ during plains larkspur grazing trials during summer, 1996 and 1997 (Cheyenne), and 1998 and 1999 ( Laramie), Wyo.

\begin{tabular}{lcc}
\hline \hline Forage Class & \multicolumn{3}{c}{ Sample Period } \\
\hline 3 May-4 August 1996 & Begin & End \\
Grass & $663 \pm 96$ & $511 \pm 63$ \\
Forbs & $47 \pm 15$ & $100 \pm 25$ \\
Larkspur & $47 \pm 11$ & $68 \pm 12$ \\
& & \\
12 May-10 August 1997 & $322 \pm 38$ & $364 \pm 44$ \\
Grass & $36 \pm 10$ & $90 \pm 54$ \\
Forbs & $49 \pm 14$ & $63 \pm 28$ \\
Larkspur & & \\
& $37 \pm 5$ & $15 \pm 6$ \\
13 May-30 June 1998 & $125 \pm 9$ & $157 \pm 11$ \\
Dry grass & $97 \pm 11$ & $38 \pm 6$ \\
Green grass & $60 \pm 13$ & $3 \pm 2$ \\
Forbs & & \\
Larkspur & $178 \pm 14$ & $163 \pm 16$ \\
1 June-20 July 1999 & $28 \pm 17$ & $17 \pm 5$ \\
Grass & $89 \pm 18$ & $63 \pm 20$ \\
Forbs & $32 \pm 12$ & $8 \pm 3$ \\
Larkspur & & \\
Milkvetch (Astragalus drummondii) & & \\
\hline
\end{tabular}

\section{Nutrient Content of Forage}

We found no relationships between nutrient or mineral content of the forage and larkspur consumption. Plains larkspur averaged more than $13 \%$ crude protein during 1996, while grasses averaged $9 \%$ crude protein, but by the end of the study both plant types contained about $8 \%$ crude protein. Conversely, grasses contained more than $66 \% \mathrm{NDF}$, whereas larkspur averaged 34\% NDF (Fig. 3). During 1997 larkspur averaged $12 \%$ crude protein compared to $10 \%$ for grasses, but grasses and larkspur had similar crude protein concentrations after May 1997. Grasses had NDF concentrations of $61 \%$ while larkspur averaged 34\% NDF (Fig. 3).

Both larkspur and grasses were highest in mineral concentrations when immature, and concentrations decreased with maturity (Table 3). Larkspurs generally exceeded grass as a source of calcium, phosphorus, potassium, and magnesium. Both larkspur and grasses were low in copper and sodium, and had marginally low concentrations of zinc and manganese. Cobalt, molybdenum, iron and selenium concentrations were adequate during each month (data not shown for $\mathrm{Fe}$ and $\mathrm{Se}$ ).

\section{Laramie 1998 and 1999}

\section{Weather}

Average ambient temperatures were at or above normal during spring, 1998, but June 1998 was cooler than normal (Fig. 1). Conversely, precipitation was lower than normal during April and May, 1998, but

ncreased to above normal amounts during June 1998 (Fig. 1). During 1999, temperapotent alkaloid in plains larkspurs, were very low. tures were cooler than normal until July 1999 , while precipitation was at or slightly above normal in April and May 1999, then falling below normal levels in June and July 1999.

\section{Forage availability}

Forage growth was delayed by drought in spring, 1998. Grasses made up more than $50 \%$ of the standing crop, and most of the grasses had begun green growth in mid-May 1998 (Table 1). During 1999, forage growth was delayed by colder than normal weather even though precipitation was adequate, and the 1999 grazing trial started almost 3 weeks later than did the 1998 trial at the same location. When the study began, most grasses had initiated green growth, as had Drummond's milkvetch.

\section{Larkspur Density, Phenology, and Alkaloid Concentration}

Larkspur density averaged 1.7 and 1.9 plants $\mathrm{m}^{-2}$ during 1998 and 1999, respectively. The drought during 1998 retarded the development of larkspur plants, as

Table 2. Toxic alkaloid concentrationa ( $\mathrm{mg}$ toxic alkaloid $\mathrm{g}^{-1}$ plant dry matter) of plains larkspur (Delphinium geyeri) during summer grazing studies near Cheyenne, Wyo. during 1996 and 1997.

\begin{tabular}{|c|c|c|c|c|}
\hline \multirow[b]{2}{*}{$\begin{array}{l}\text { Phenological } \\
\text { Stage }\end{array}$} & \multicolumn{2}{|c|}{1996} & \multicolumn{2}{|c|}{1997} \\
\hline & Date & $\begin{array}{l}\text { Toxic alkaloid } \\
\text { Concentration }\end{array}$ & Date & $\begin{array}{l}\text { Toxic alkaloid } \\
\text { Concentration }\end{array}$ \\
\hline Vegetative & $\begin{array}{l}\text { 3 May } \\
10 \text { May } \\
17 \text { May } \\
24 \text { May } \\
\text { 31 May } \\
7 \text { June } \\
\text { 14 June } \\
28 \text { June } \\
5 \text { July }\end{array}$ & $\begin{array}{c}--\left(\mathrm{mg} \mathrm{g}^{-1}\right)-- \\
7.0 \\
5.1 \\
4.9 \\
3.9 \\
4.1 \\
3.3 \\
3.2 \\
2.1 \\
1.4\end{array}$ & $\begin{array}{r}14 \text { May } \\
21 \text { May } \\
28 \text { May } \\
\text { 4 June }\end{array}$ & $\begin{array}{c}-\left(\mathrm{mg} \mathrm{g}^{-1}\right)-- \\
4.7 \\
3.9 \\
3.0 \\
2.6\end{array}$ \\
\hline Bud & $\begin{array}{l}\text { 31 May } \\
7 \text { June } \\
14 \text { June } \\
21 \text { June } \\
28 \text { June } \\
5 \text { July }\end{array}$ & $\begin{array}{l}3.9 \\
3.2 \\
3.8 \\
3.6 \\
3.5 \\
3.0\end{array}$ & $\begin{array}{l}\text { 4 June } \\
11 \text { June } \\
17 \text { June } \\
25 \text { June } \\
1 \text { July }\end{array}$ & $\begin{array}{l}3.0 \\
2.8 \\
3.4 \\
2.7 \\
2.4\end{array}$ \\
\hline Flower & $\begin{array}{l}14 \text { June } \\
21 \text { June } \\
28 \text { June } \\
5 \text { July } \\
12 \text { July } \\
10 \text { July } \\
26 \text { July }\end{array}$ & $\begin{array}{l}3.6 \\
3.4 \\
3.3 \\
3.5 \\
2.8 \\
2.8 \\
1.8\end{array}$ & $\begin{array}{l}1 \text { July } \\
9 \text { July } \\
16 \text { July }\end{array}$ & $\begin{array}{l}4.2 \\
3.0 \\
2.6\end{array}$ \\
\hline Pod & $\begin{array}{l}12 \text { July } \\
19 \text { July } \\
26 \text { July } \\
2 \text { August }\end{array}$ & $\begin{array}{l}4.0 \\
2.6 \\
2.4 \\
2.1\end{array}$ & $\begin{array}{l}23 \text { July } \\
31 \text { July } \\
6 \text { August }\end{array}$ & $\begin{array}{l}4.0 \\
3.9 \\
4.0\end{array}$ \\
\hline
\end{tabular}

${ }^{a}$ Larkspur samples were composites of twenty individual plants. Toxic alkaloid concentrations indicate the amount of MSAL-type alkaloids, of which methyllycaconitine (MLA) is the dominant alkaloid. Concentrations of nudicauline, a 

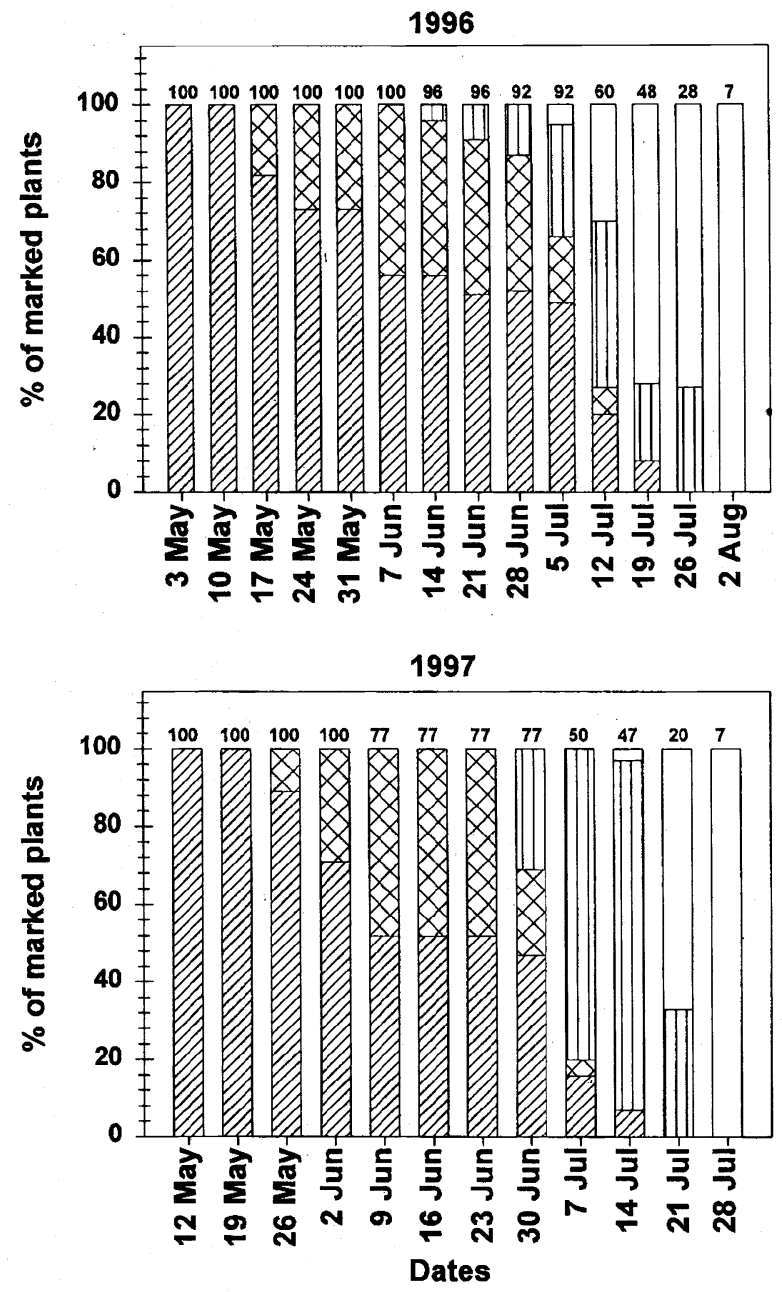

एयु Vegetative $\square \times$ Bud $[1]$ Flower $\square$ Pod

Fig. 2. Proportions (\% of marked plants) of plains larkspur (Delphinium geyeri) in various phenological growth stages during summer, 1996 and 1997, near Cheyenne, Wyo. Thirty plants were marked during each year. The number on top of each bar represents the percentage of marked plants still alive when the observations were taken.

most died before flowering (Fig. 4). In addition, larkspur plants appeared to be shorter than normal although we did not measure height. Larkspur growth was delayed during May 1999 from colder than normal temperatures, and most plants were vegetative or in the bud stage when the trial began in early June. Dry conditions during June and July also hampered the development of larkspur plants, and most dried out in early July without producing pods.

Plains larkspur plants were moderately high $\left(>5 \mathrm{mg} \mathrm{g}^{-1}\right)$ in toxic alkaloid concentration at the beginning of the trials in both 1998 and 1999. Toxic alkaloid concentrations remained relatively stable (about 3 to $4 \mathrm{mg} \mathrm{g}^{-1}$ ) throughout both grazing trials (Table 4). Drummond's milkvetch contained very low concentrations $(<0.1 \%)$ of the indolizidine alkaloid, swainsonine (Gardner, unpublished data). consumption during 1998, but not 1999, was negatively related $\left(r^{2}=0.43\right)$ to maximum and minimum daily temperature. The regression equation relating temperature to larkspur consumption was $\mathrm{y}=12.4$ $-0.16 \mathrm{x}-0.09 \mathrm{z}$, where $\mathrm{y}$ is larkspur consumption, $\mathrm{x}$ is minimum daily temperature (degree $\mathrm{C}$ ) and $\mathrm{z}$ is maximum daily temperature.

Larkspur averaged $<0.01,0.9$ and $4.8 \%$ of bites $(\mathrm{P}<0.05)$ for the 3 periods in 1999 corresponding to early, mid-, and late-maturity for larkspur, respectively (Fig. 5). Grasses comprised 96, 88, and $82 \%$ of bites during periods 1 to 3 , respectively, during 1999. Cattle ate substantial amounts (7 to 10\% of bites) of Drummond's milkvetch during periods 2 and 3 , whereas consumption of other forbs (exclusive of larkspur and milkvetch) did not exceed 5\% of bites in any period.

\section{Nutrient Content of Forage}

Plains larkspur averaged $12 \%$ and $32 \%$ crude protein and NDF, respectively, during 1998 (Fig. 3). During 1999 larkspur averaged $9.5 \%$ crude protein compared to $9.8 \%$ for grasses. The crude protein content of plains larkspur was negatively related to weekly larkspur consumption $\left(\mathrm{r}^{2}\right.$ $=0.51$ ) during 1999 as cattle ate more larkspur when plants were maturing (Fig. 5). Grasses had NDF concentrations of 59\% while larkspur averaged 33\% NDF during 1999. Drummond's milkvetch and other forbs had higher crude protein concentrations and similar NDF concentrations compared to the other forage types.

All measured mineral elements except $\mathrm{Zn}$ increased in plains larkspur from June to July, 1998 (Table 5). Larkspur plants increased mineral concentrations greatly (except for $\mathrm{Zn}$ ) from the June to July, 1998 sampling periods. None of the different forage types contained adequate $\mathrm{Na}$ concentrations for lactating cattle (NRC 1996); except for forbs, all forage types were also inadequate in Mn concentration. Grasses were low in both $\mathrm{P}$ and $\mathrm{Zn}$ in June and July 1999. Furthermore, weekly larkspur consumption during both 1998 and 1999 was related to $\mathrm{Zn}$ concentration in plains larkspur $\left(r^{2}=0.58\right.$ and 0.79 , respectively). No other mineral variables were related to larkspur consumption ( $\mathrm{P}>$ 0.15 ).

\section{Discussion}

bouts where larkspur exceeded 15-20\% of bites, and numerous animals were visibly intoxicated (i.e., staggering and sternal recumbency). No animals were fatally intoxicated during the study. Larkspur 
Table 3. Mineral concentration ( $\mathrm{mg} \mathrm{kg}^{-1}$ ) of plains larkspur and grasses during summer, 1996-1997 near Cheyenne, Wyo.

\begin{tabular}{|c|c|c|c|c|c|c|c|c|}
\hline \multirow[b]{2}{*}{ Element $^{\mathrm{a}}$} & \multicolumn{2}{|c|}{ May } & \multicolumn{2}{|c|}{ June } & \multicolumn{2}{|c|}{ July } & \multicolumn{2}{|c|}{ August } \\
\hline & Larkspur & Grass & Larkspur & Grass & Larkspur & Grass & Larkspur & Grass \\
\hline & & & & & $\begin{array}{c}1996 \\
\left(\mathrm{mg} \mathrm{kg}^{-1}\right)-\end{array}$ & & & \\
\hline $\mathrm{Ca}$ & 16895.5 & 2959.7 & 21865.6 & 2853.6 & 22204.5 & 3424.8 & 19506.7 & 4022.6 \\
\hline K & 37255.1 & 11488.2 & 27198.4 & 11611.8 & 19740.7 & 8569.7 & 15839.0 & 8053.8 \\
\hline $\mathrm{Mg}$ & 2760.5 & 565.7 & 2209.4 & 623.1 & 2197.3 & 611.9 & 1733.4 & 649.0 \\
\hline $\mathrm{Na}$ & 25.2 & 22.0 & 21.8 & 11.4 & 24.6 & 10.7 & 42.4 & 6.2 \\
\hline $\mathrm{Cu}$ & 9.5 & 3.7 & 6.6 & 4.0 & 4.3 & 2.9 & 3.1 & 2.6 \\
\hline Co & 0.08 & 0.07 & 0.08 & 0.04 & 0.07 & 0.06 & 0.05 & 0.05 \\
\hline $\mathrm{Mn}$ & 43.9 & 31.0 & 29.2 & 23.6 & 17.7 & 18.6 & 11.6 & 22.2 \\
\hline Mo & 1.2 & 1.4 & 1.6 & 1.8 & 1.5 & 1.7 & 0.7 & 1.8 \\
\hline $\mathrm{P}$ & 3377.0 & 1877.9 & 2341.2 & 1932.2 & 1894.5 & 1348.6 & 1724.9 & 1120.4 \\
\hline \multirow[t]{2}{*}{$\mathrm{Zn}$} & 26.9 & 16.9 & 22.2 & 15.6 & 18.9 & 12.6 & 17.6 & 12.3 \\
\hline & & & & & $\begin{array}{c}1997 \\
\left(\mathrm{mg} \mathrm{kg}^{-1}\right)\end{array}$ & & & $\ldots$ \\
\hline $\mathrm{Ca}$ & 17566.1 & 3374.1 & 18480.7 & 3197.2 & 18323.2 & 3542.5 & 2914.1 & 3148.2 \\
\hline K & 37086.8 & 13593.9 & 25306.6 & 15481.7 & 15503.3 & 12121.7 & 911.4 & 8556.6 \\
\hline $\mathrm{Mg}$ & 2971.7 & 683.0 & 1964.8 & 765.1 & 1416.5 & 666.9 & 230.1 & 632.1 \\
\hline $\mathrm{Na}$ & 151.7 & 14.9 & 134.4 & 12.8 & 127.9 & 21.7 & 3.9 & 42.4 \\
\hline $\mathrm{Cu}$ & 7.8 & 4.3 & 7.0 & 4.3 & 5.9 & 3.5 & 0.7 & 5.6 \\
\hline Co & 0.07 & 0.07 & 0.09 & 0.04 & 0.49 & 0.04 & 0.03 & 0.04 \\
\hline $\mathrm{Mn}$ & 34.7 & 28.2 & 35.3 & 27.9 & 20.7 & 19.6 & 2.3 & 26.4 \\
\hline Mo & 0.6 & 1.6 & 1.1 & 1.3 & 1.4 & 1.6 & 0.4 & 1.2 \\
\hline $\mathrm{P}$ & 3334.9 & 2103.6 & 3530.4 & 2507.6 & 2258.5 & 1700.5 & 253.2 & 1671.1 \\
\hline $\mathrm{Zn}$ & 22.3 & 34.3 & 24.1 & 20.1 & 176.4 & 14.9 & 10.3 & 15.6 \\
\hline
\end{tabular}

${ }^{\mathrm{a}}$ Requirements $\left(\mathrm{mg} \mathrm{kg}^{-1}\right)$ of mature beef cow during early lactation: $\mathrm{Ca}-3400 ; \mathrm{K}-8000 ; \mathrm{Mg}-2000 ; \mathrm{Na}-1000 ; \mathrm{Cu}-10 ; \mathrm{Co}-0.1 ; \mathrm{Mn}-40 ; \mathrm{Mo}-<5 ; \mathrm{P}-2400 ; \mathrm{Zn}-30 . \mathrm{Source}$ : NRC (1996).

during brief periods in May of each year. Those brief periods were (with one major exception on 17 May 1996) characterized by cool, foggy weather conditions. Even so, cattle were very inconsistent and ate no larkspur on many damp, cool days. The very low consumption of plains larkspur in the Cheyenne grazing trials was unexpected because plains larkspur populations were abundant and livestock losses are common in this area (A.P. Knight, personal communication). Nonetheless, reported livestock losses were few during the spring and summer of both 1996 and 1997. We are aware of fewer than 10 reported cattle deaths during both summers in the Cheyenne area. Larkspur was not highly toxic during most of both summers (i.e., $<4 \mathrm{mg} \mathrm{g}^{-1}$ of toxic alkaloid), and we surmise that consumption of larkspur in our grazing trials mirrored trends in the local cattle herds.

We have no plausible explanation for the low consumption during the 2 summers in Cheyenne. The Cheyenne site had abundant grass each year, and most of the cattle diets were composed of grasses. Local ranchers believe that cattle tend to eat more plains larkspur early in the season when plains larkspur has initiated growth, but grasses lag behind in green growth. Even though we began the studies in May each year when plains larkspur was only $3-6 \mathrm{~cm}$ tall, cattle ate little or no larkspur during these times. Ranchers also have suggested that cattle eat plains larkspur during flowering, but consumption was essentially 0 during flowering at the Cheyenne site. The study was not designed to compare larkspur consumption at Cheyenne and Laramie, and any comparisons are confounded over time. Even so, availability of grasses was higher at Cheyenne than at Laramie, and this may have influenced cattle consumption of plains larkspur. In contrast, cattle ate most

larkspur in Laramie during early July 1999, when grass was relatively abundant and availability of the most preferred forb, Drummond's milkvetch, was greatly reduced by grazing.

In previous work we have shown that alkaloid (Pfister et al. 1996) or carbohydrate (Ralphs, unpublished data) concentrations have little impact on consumption of tall larkspurs by cattle. In some summers cattle have eaten low amounts of tall

Table 4. Toxic alkaloid concentrationa (mg toxic alkaloid $\mathrm{g}^{-1}$ plant dry matter) of plains larkspur (Delphinium geyeri) during summer grazing studies near Laramie, Wyo. during 1998 and 1999.

\begin{tabular}{|c|c|c|c|c|}
\hline \multirow[b]{2}{*}{$\begin{array}{l}\text { Phenological } \\
\text { Stage }\end{array}$} & \multicolumn{2}{|c|}{1998} & \multicolumn{2}{|c|}{1999} \\
\hline & Date & $\begin{array}{l}\text { Toxic alkaloid } \\
\text { Concentration }\end{array}$ & Date & $\begin{array}{l}\text { Toxic alkaloid } \\
\text { Concentration }\end{array}$ \\
\hline Vegetative & $\begin{array}{l}16 \text { May } \\
23 \text { May } \\
30 \text { May }\end{array}$ & $\begin{array}{c}-\left(\mathrm{mg} \mathrm{g}^{-1}\right)-- \\
5.4 \\
4.7 \\
4.1\end{array}$ & $\begin{array}{l}2 \text { June } \\
12 \text { June }\end{array}$ & $\begin{array}{l}--\left(\mathrm{mg} \mathrm{g}^{-1}\right)-- \\
5.1 \\
4.7\end{array}$ \\
\hline Bud & $\begin{array}{l}5 \text { June } \\
13 \text { June } \\
\text { 20 June }\end{array}$ & $\begin{array}{l}3.9 \\
3.6 \\
4.2\end{array}$ & $\begin{array}{l}2 \text { June } \\
12 \text { June } \\
18 \text { June }\end{array}$ & $\begin{array}{l}4.3 \\
4.2 \\
4.3\end{array}$ \\
\hline Flower & 27 June & 4.3 & $\begin{array}{l}18 \text { June } \\
25 \text { June } \\
3 \text { July }\end{array}$ & $\begin{array}{l}3.6 \\
4.5 \\
4.5\end{array}$ \\
\hline Pod & - & - & $\begin{array}{l}9 \text { July } \\
16 \text { July }\end{array}$ & $\begin{array}{l}3.5 \\
3.8\end{array}$ \\
\hline
\end{tabular}

${ }^{a}$ Larkspur samples were composites of twenty individual plants. Toxic alkaloid concentrations indicate the amount of MSAL-type alkaloids, of which methyllycaconitine (MLA) is the dominant alkaloid. Concentrations of nudicauline, a potent alkaloid in plains larkspurs, were very low. Larkspur plants did not produce pods during the drought of 1998 . 

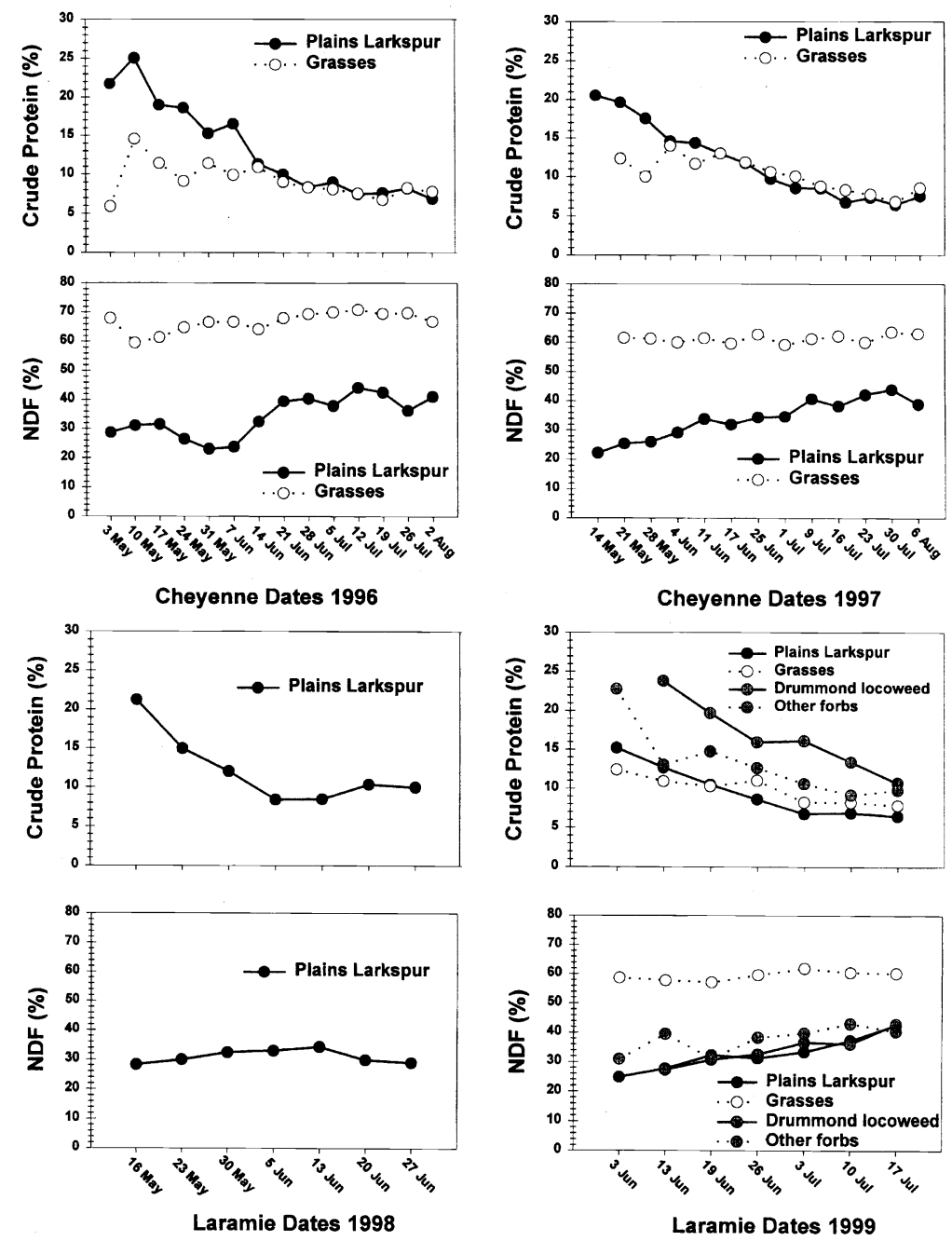

Fig. 3. Crude protein and NDF (\% of dry matter) concentrations in weekly composited forage samples from grazing studies in Cheyenne and Laramie, Wyo. during the summers of 1996, 1997, 1998, and 1999.
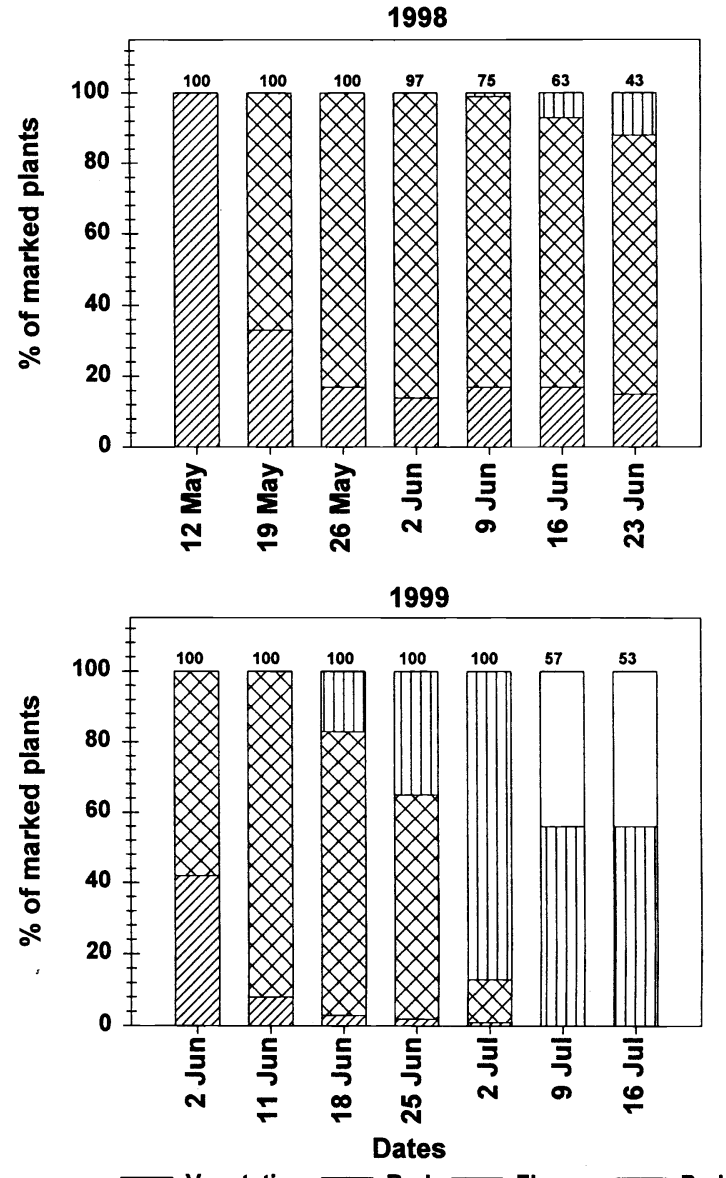

एय] Vegetative खx Bud 피 Flower $\square$ Pod

Fig. 4. Proportions (\% of marked plants) of plains larkspur (Delphinium geyeri) in various phenological growth stages during summer, 1998 and 1999, near Laramie, Wyoming. Thirty plants were marked during each year. The number on top of each bar represents the percentage of marked plants still alive when the observations were taken. larkspurs (Pfister et al. 1999), and we have attributed these patterns to summer drought (Pfister and Manners 1991, 1995). Unlike tall larkspurs, there was no indication that consumption of plains larkspur was reduced during drought except that limited moisture at Laramie in 1998 reduced plains larkspur phytomass and hence availability to grazing animals.

Different larkspur consumption patterns emerged in the Laramie grazing studies. During 1998, cattle ate substantial amounts of plains larkspur during the vegetative and bud stages from mid-May into early June. The drought during spring 1998, severely retarded growth of both larkspur and grasses; plains larkspur never recovered from this lack of initial moisture and much of the shorter-than-normal larkspur in the pasture had either been grazed or was desiccated and dead when the study ended. Cattle may have eaten more larkspur in response to the reduced availability of green grass early in the grazing season. On the contrary, during 1999 cattle ate essentially no plains larkspur during the vegetative and bud stages, but ate most larkspur during the flower and pod stages. The study pasture had adequate spring (i.e., April and May) moisture during 1999 , but received lower than normal precipitation during June and July.

Cattle had somewhat different daily eating patterns during the 2 summer trials in Laramie. Cattle ate larkspur at various times throughout the day in 1998, but particularly at times when cooler temperatures prevailed. Damp, cold, and fog seemed to be associated with plains larkspur consumption for reasons that are not clear. We have noted in other studies that cattle avidly eat other larkspur species during cooler and wetter periods (Pfister et al. 1988, Ralphs et al. 1994). Even though the early summer of 1999 was colder than normal, we did not find a relationship between temperature and larkspur consumption, as cattle ate little larkspur during the cooler period. Most larkspur consumption occurred during early July when larkspur plants were beginning to dry out and average daily temperatures were at or above normal.

Larkspur consumption averaged over groups of animals does not clearly show trends by individual animals (Pfister et al. 1997a). We consolidated larkspur selection data for each animal from 3 consecutive observation periods, termed here as a grazing bout, when larkspur consumption was highest during each day. Individual maxima clearly highlight the periods of greatest consumption in Laramie during 
Table 5. Mineral concentration ( $\mathrm{mg} \mathrm{k}^{-1}$ ) of plains larkspur and grasses during summer, 1998-1999 near Laramie, Wyoming.

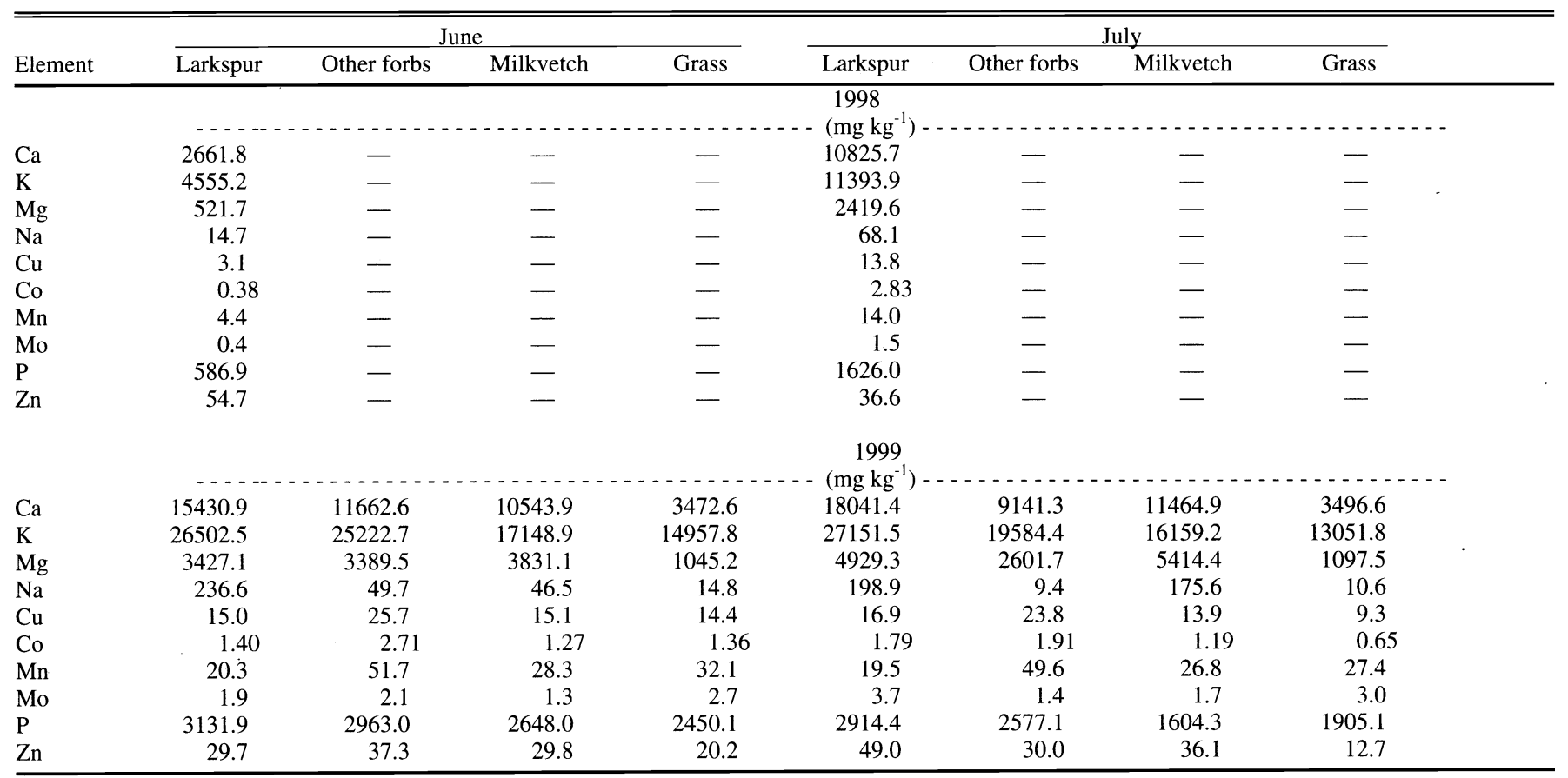

1998 and 1999 (Fig. 5). Larkspur consumption by individual animals often exceeded $20 \%$ of their diet during these grazing bouts, and in some cases exceeded $50 \%$ of bites. We have shown in other work that cattle consume tall larkspur in a cyclic fashion, with days of higher consumption followed by a detoxification period and lower consumption for 1 or 2 days (Pfister et al. 1997a). Cattle in the Laramie grazing studies followed a similar cyclic pattern. It was particularly noteworthy that larkspur consumption sufficient to cause temporary intoxication (i.e., short term paralysis and recumbency) was usually followed by very low consumption for 1 or 2 days.

We periodically monitored calves for diet selection for 2 or 3 minutes for each observation, although total grazing activity by calves was sporadic and often of short duration. Calves in all the grazing studies appeared to graze larkspur in concert with their adult cohorts. Calves ate essentially no larkspur in Cheyenne, whereas consumption in the Laramie trials was sometimes very high ( $>50 \%$ of bites) for brief periods. We speculate that consumption as calves predisposes these individuals to greater acceptability of larkspur in future years, as noted by studies on other plants (Distel and Provenza 1991, Distel et al. 1996), but we have not tested this notion.

\section{Larkspur Consumption and Forage Nutrient Concentration}

One commonly recommended means to reduce larkspur losses is through mineral supplementation (Hughes 1941, Logan 1973, Knowles 1974). Anecdotal accounts suggest that dicalcium phosphate is often supplemented in hopes of reducing larkspur consumption by cattle. Larkspur is an excellent source of $\mathrm{Ca}$, generally far exceeding the $3,000 \mathrm{mg} \mathrm{kg}^{-1}$ requirement for lactating animals; grasses also often exceeded this required amount of $\mathrm{Ca}$.

The forage $\mathrm{P}$ requirement for early lactating cows is $1900 \mathrm{mg} \mathrm{kg}^{-1}$ (forage dry wt., NRC 1996), and larkspur often exceeded this amount whereas grasses were sometimes deficient (Tables 3 and 5). Cattle ate substantial amounts of larkspur in late May and early June 1998 when plains larkspur had low P concentrations. During a period of major larkspur consumption in July 1999, grasses and larkspur both met or exceeded $\mathrm{P}$ requirements.

The ideal $\mathrm{Ca}: \mathrm{P}$ ratio is $1: 1$ but not greater than 7:1 (NRC 1996); the ratio in larkspur was 9.3, 7.5, 5.6 and 5.6 in 1996 to 1999 , respectively. The Ca:P ratio in grasses was generally 1.5 to 1.7 (Tables 3 and 5). Cattle ate little or no larkspur when the Ca:P ratio was highest in 1996 and 1997, suggesting that high Ca concentrations in larkspur do not promote increased consumption, at least in cows that are grazing grasses with an adequate $\mathrm{Ca}: \mathrm{P}$ ratio. It is possible that $\mathrm{Ca}$-deficient cows might eat more Ca-rich larkspur, but it doesn't appear that grasses in this region are deficient in $\mathrm{Ca}$ during early to midsummer.

As expected, the forage in all 4 years was deficient in $\mathrm{Na}$. Both grasses and larkspur were deficient in $\mathrm{Cu}$ (i.e, $<10 \mathrm{mg} \mathrm{kg}^{-1}$ ) at the Cheyenne site during both summers, but $\mathrm{Cu}$ concentrations were adequate in both grasses and larkspur during 1999 in Laramie. Zinc was the only mineral element in larkspur that was related to consumption, and this relationship was observed during both 1998 and 1999 in Laramie. Zinc concentrations were generally inadequate $\left(<30 \mathrm{mg} \mathrm{kg}{ }^{-1}\right)$ in forage from Cheyenne; except for grasses, forages in Laramie contained adequate $\mathrm{Zn}$ concentrations. Because other forages in Laramie also contained adequate zinc concentrations, it is not clear if the association between zinc concentration and larkspur consumption is biologically significant.

Plains larkspur was generally higher in protein than were grasses early in the growing season, but differences were usually minor after larkspur matured. Crude protein concentration of larkspur in Laramie during 1999 was negatively related to larkspur consumption because cattle ate more larkspur when larkspur was maturing and nitrogen concentrations were declining. We doubt if crude protein concentration had any real effect on larkspur consumption. 

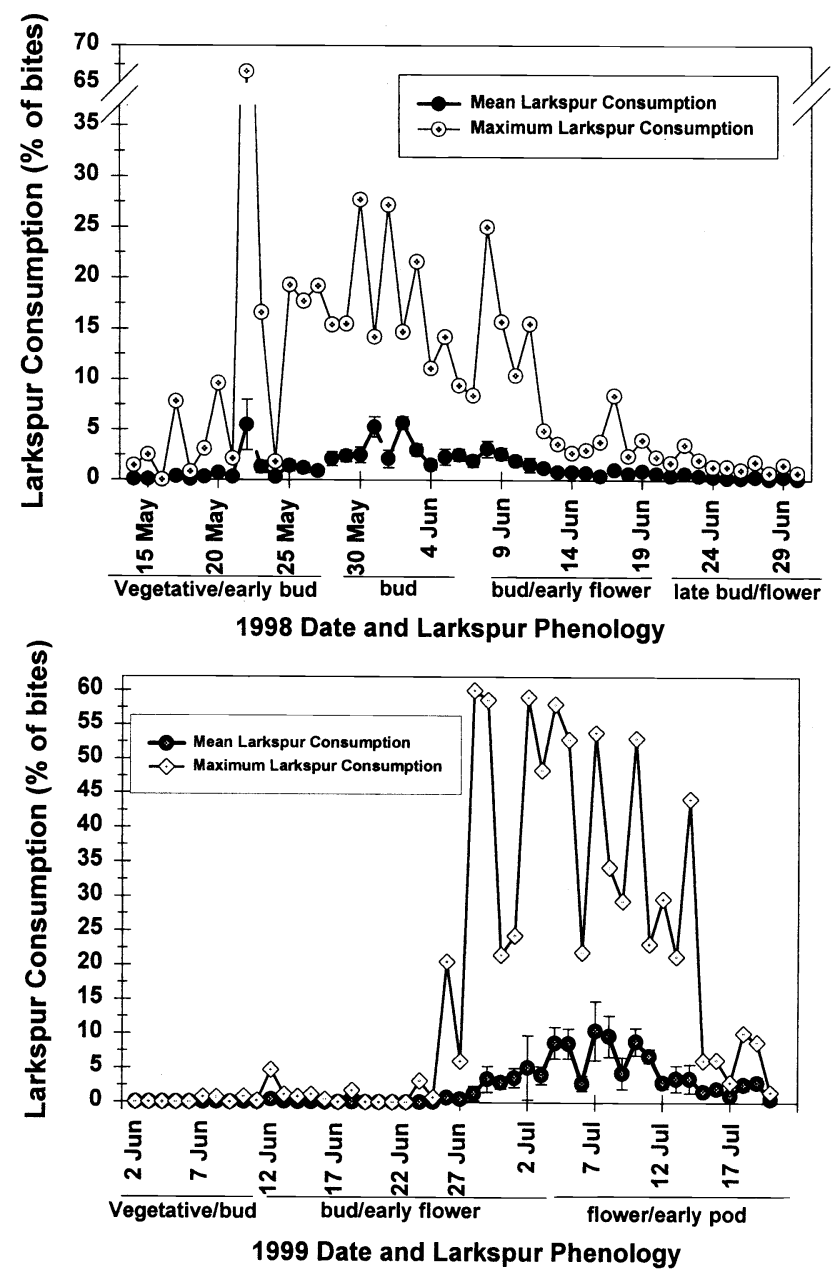

Fig. 5. Larkspur consumption (\% of bites) by cattle during spring and summer, 1998 to 1999, near Laramie, Wyo. Mean larkspur consumption reflects mean consumption by all experimental cows. Maxima reflect larkspur consumption data that were consolidated for each experimental animal from 3 consecutive observation periods, termed here as a grazing bout, when larkspur consumption was highest during each day. Only the single highest daily maximum from among all grazing animals (i.e., one animal) is shown.

Results for protein and NDF are typical of comparisons between forbs and grasses (Cook and Harris 1968, Abouguendia 1998, Perez Corona et al. 1998). Taken together, there was little evidence that consumption (or lack thereof) of larkspur was driven by mineral or nutrient concentrations. As with tall larkspurs, we recommend that livestock producers make supplementation decisions based on forage deficiencies and cattle nutrient requirements, but not as a basis for altering consumption of larkspur by cattle (Pfister and Manners 1991, 1995).

\section{Toxicity of Plains Larkspur}

No toxicology studies have established the threshold of toxicity for plains larkspur in cattle. Therefore we estimated the amount of larkspur that constituted a toxic dose of plains larkspur. Grazing cattle often displayed signs of larkspur toxicosis during May and early June 1998, and early July 1999 , as on many occasions cattle were temporarily paralyzed and unable to walk or stand. We did not treat any intoxicated animals, although at times we were uncertain if the affected cattle would survive (none died). Affected cattle averaged $5 \%$ of total daily bites $(\mathrm{n}=24, \overline{\mathrm{x}}=5.1, \mathrm{SD}$ $=2.6$ ) as plains larkspur on days when overt toxicity was noted. Cattle had total biting rates of about 45 bites minute ${ }^{-1}$. Individual larkspur plants weighed 1.5 to 2 g plant $^{-1}$ (dry wt.) and cattle generally ingested most or all of one larkspur plant bite $^{-1}$ (Pfister unpublished data). Thus, on a typical day $(\sim 10$ hours of actual grazing time) during this period cattle ingested about 1,350 bites of larkspur day ${ }^{-1}$ or 2.0 to $2.7 \mathrm{~kg}$ of larkspur day ${ }^{-1}$. We note that larkspur consumption is typically not steady during the day, but cattle often have grazing bouts when much of the diet consists of larkspur. Larkspur during this period averaged about 4 to $5 \mathrm{mg}$ toxic alkaloid $\mathrm{g}^{-1}$ dry wt. (Table 4), thus cattle were ingesting about 8.1 to $13.5 \mathrm{~g} \mathrm{day}^{-1}$ of alkaloid. A toxic, but not fatal, dose of tall larkspur alkaloids in cattle is $21 \mathrm{mg} \mathrm{kg}^{-1}$ body weight (Pfister et al. 1994). For cattle weighing $500 \mathrm{~kg}$, the $21 \mathrm{mg} \mathrm{kg}^{-1}$ value indicates a toxic alkaloid dose of about $10.5 \mathrm{~g}$. From these calculations it appears that plains larkspur has similar or perhaps slightly greater toxicity than tall larkspurs. Interestingly, we did not observe as many cases of overt intoxication during 1999 as during 1998, even though cattle ate more larkspur at times during 1999. Toxic alkaloid concentrations were similar, and differences in eating patterns may have been responsible. As previously noted, during 1998 cattle ate larkspur steadily throughout the day, whereas consumption in 1999 was characterized by more rapid consumption during fewer grazing bouts. Both sets of experimental animals were lactating, but during 1998 the cows were in a lower body condition than during 1999. Lower body condition may alter the absorption and elimination patterns of toxic alkaloids (Lopez and Launchbaugh, unpublished data), thus rendering thin animals more susceptible to intoxication.

\section{Conclusions}

This series of trials suggests that it will be difficult to predict plains larkspur consumption based on larkspur growth patterns, nutrient concentrations, or weather. As with tall larkspurs, cattle sometimes increased plains larkspur consumption when temperatures were cooler than normal. Nonetheless, this pattern was not consistent and therefore will not serve as a basis for management recommendations that can reduce risk and losses. Currently, our best management recommendation is to ensure that other desirable forage production is ample when cattle graze in plains larkspur-infested pastures. Extra caution may be warranted if cattle are in low body condition. Additionally, if losses persist from year-to-year, the flat terrain in many areas may provide an opportunity to use tractor-mounted herbicidal control to reduce dense larkspur patches. Whitson et al. (1992) has shown that herbicidal control of plains larkspurs can effectively reduce dense populations. 


\section{Literature Cited}

Abouguendia, Z. 1998. Seasonal pattern of nutrient content of native plants: an overview. The Grazing Gazette, Vol. 7, No.1, Grazing and Pasture Tech. Prog., Regina, Sask., Can.

Altmann, J. 1974. Observational study of behavior: sampling methods. Behav. 49:227-267.

AOAC. 1990. Official Methods of Analysis $\left(15^{\text {th }}\right.$ Ed.). Assoc. of Official Analytical Chemists, Washington, D.C.

Beath, O.A. 1919. The chemical examination of three species of larkspurs. Univ. Wyoming Agr. Exp. Sta. Bull. 120.

Beath, O.A. 1925. Chemical examination of three Delphiniums. Univ. Wyoming Agr. Exp. Sta. Bull. 143.

Chesnut, V.K. 1898. Thirty poisonous plants of the United States. USDA Farmers Bull. 86.

Cook, C.W. and L.E. Harris. 1968. Nutritive value of seasonal ranges. Utah Agr. Exp. Sta. Bull. 472.

Distel, R.A. and F.D. Provenza. 1991. Experience early in life affects voluntary intake of blackbrush by goats. J. Chem. Ecol. 17:431-449.

Distel, R.A., J.J. Villalba, H.E Laborde, and M.A. Burgos. 1996. Persistence of the effects of early experience on consumption of low-quality roughage by sheep. J. Anim. Sci. 74:965-968.

Gardner, D.R., K.E. Panter, J.A. Pfister, and A.P. Knight. 1999. Analysis of toxic norditerpenoid alkaloids by electrospray, atmospheric pressure chemical ionization, and sequential tandem mass spectrometry. J. Agr. Food Chem. 47:5049-5058.

Hart, R.H. and M.J. Samuel. 1985. Precipitation, soils and herbage production on southeastern Wyoming range sites. J. Range Manage. 38:522-525.
Hughes, H.R. 1941. Larkspur poisoning preventative. San Juan District, Rocky Mountain Regional Bull., USDA Forest Service.

Knowles, K. 1974. An evaluation of larkspur poisoning in cattle and the trampling damage that occurs during grazing on a summer range in eastern Idaho. M.S. Thesis, Univ. of Idaho, Moscow, Ida.

Logan, J.R. 1973. Evaluation of a specificallyformulated supplement for the prevention of larkspur poisoning in cattle. M.S. thesis. Utah State Univ., Logan, Ut.

Manners, G.D., K.E. Panter, and S.W. Pelletier. 1995. Structure-activity relationships of norditerpenoid alkaloids occurring in toxic larkspur (Delphinium) species. J. Nat. Prod. 58:863-869.

NRC. 1996. National Research Council. Nutrient requirements of beef cattle. 7 th revised ed. National Academy Press, Washington, D.C.

Perez Corona, M.E., B.R.V. de Aldana, B.G. Criado, and A.G. Ciudad. 1998. Variations in nutritional quality and biomass production of semiarid grasslands. J. Range Manage. 51:570-576.

Pfister, J.A. and G.D. Manners. 1991. Mineral supplementation of cattle grazing larkspur-infested rangeland during drought. J. Range Manage. 44:105-111.

Pfister, J.A. and G.D. Manners. 1995. Effects of carbachol administration in cattle grazing tall larkspur-infested range. J. Range Manage. 48:343-349.

Pfister, J.A., K.E. Panter, and G.D. Manners. 1994. Effective dose in cattle of toxic alkaloids from tall larkspur (Delphinium barbeyi). Vet. Human Toxicol. 36:10-11.

Pfister, J.A., G.D. Manners, D.R. Gardner, K.W. Price, and M.H. Ralphs. 1996. Influence of alkaloid concentration on acceptability of tall larkspur (Delphinium spp.) to cattle and sheep. J. Chem. Ecol. 22:1147-1168.
Pfister, J.A., G.D. Manners, M.H. Ralphs, Z.X. Hong, and M.A. Lane. 1988. Effects of phenology, site and rumen fill on tall larkspur consumption by cattle. J. Range Manage. 41:509-514.

Pfister, J.A., F.D. Provenza, G.D. Manners, D.R. Gardner, and M.H. Ralphs. 1997a. Tall larkspur ingestion: can cattle regulate intake below toxic levels? J. Chem. Ecol. 23:759-777.

Pfister, J.A., M.H. Ralphs, G.D. Manners, D.R. Gardner, K.W. Price, and L.F. James. 1997b. Early season grazing of tall larkspur- (Delphinium spp.) infested rangeland. J. Range Manage. 50:391-398.

Pfister, J.A., D.R. Gardner, K.E. Panter, G.D. Manners, M.H. Ralphs, B.L. Stegelmeier, and T.K. Schoch. 1999. Larkspur (Delphinium spp.) poisoning in livestock. J. Nat. Toxins 8:81-94

Ralphs, M.H., D.T. Jensen, J.A. Pfister, D.B. Nielsen, and L.F. James. 1994. Storms influence cattle to graze larkspur: an observation. J. Range Manage. 47:275-278.

Rauzi, F. 1964. Late-spring herbage production on shortgrass rangeland. J. Range Manage. 17:210-212.

SAS. 1998. SAS/STAT guide for personal computers, Ver. 7. SAS Institute, Cary, N.C.

Smith, R. 1994. Handbook of Environmental Analysis, $2^{\text {nd }}$ Ed. Genium Publishing Co., Schenectady, N.Y.

Van Soest, P.J., J.B. Robertson, and B.A. Lewis. 1991. Methods for dietary fiber, neutral detergent fiber, and non-starch polysaccharides in relation to animal nutrition. J. Dairy Sci. 74: 3583-3597.

Whitson, T.D., W.R. Tatman, and R.J. Swearingen. 1992. Control of geyer larkspur (Delphinium geyeri Greene) at two growth stages with various herbicides. West. Sec. Weed Sci. Soc. Res. Prog. Rep. I 64-65. 